\title{
Public Interest Litigation and Human Rights Implementation: The Indian and Australian Experience*
}

\author{
Christine M. Forster and Vedna Jivan
}

\begin{abstract}
Public interest litigation ['PIL'], typically defined as proceedings in which the public or the community at large has some pecuniary or legal interest, demonstrates an ability to foster human rights compliance. It does this by enabling broader community or 'public' interests to be recognised and enforced through the judicial process, thereby revealing greater potential than private rights litigation in addressing the systemic nature of many human rights violations. This in turn has presented greater opportunities domestically to monitor each state's accountability to international human rights standards.
\end{abstract}

This paper compares and contrasts the emergence and development of PIL in two jurisdictions - India and Australia. India was chosen for its remarkable and extensive development of PIL unparalleled in Commonwealth jurisdictions to date, and Australia, for its adoption of a much more restrained and traditional trajectory in line with other members of the Commonwealth. Although PIL has developed differently in the two countries, inevitably shaped by differences in culture, economic development, law and politics, both provide illustrations of PIL's potential (and limitations) in facilitating the development of human rights norms in domestic legal systems.

KEYWORDS: public interest litigation, human rights implementation, India, Australia, comparative

${ }^{*}$ Dr. Christine Forster, Senior Lecturer, Faculty of Law, University of New South Wales, Sydney, Australia; Vedna Jivan Senior Lecturer, Faculty of Law, University of Technology Sydney, Sydney Australia. The writers would like to thank the anonymous referees for their very helpful comments on an earlier draft. 
Forster and Jivan: Public Interest Litigation in India \& Australia

\section{INTRODUCTION}

The United Nations High Commissioner for Human Rights observed in 1995 "there is no shortage of international human rights standards nor unfortunately is there a shortage of situations demanding improvement of respect for human rights. Our basic challenge is to implement human rights standards and make human rights meaningful in people's lives." ${ }^{1}$ Historically, the implementation of human rights has largely relied on a state's willingness to meet its human rights obligations. In its absence, as implied by the Commissioner, the critical inquiry lies in finding effective means of engendering state compliance. ${ }^{2}$ Both external modes of enforcement such as reporting and complaints procedures and internal mechanisms such as private rights litigation have proven limited in securing human rights compliance. ${ }^{3}$ This article argues that public interest litigation (PIL), typically defined as proceedings in which the public or the community at large has some pecuniary or legal interest, ${ }^{4}$ whilst not a panacea for remedying human rights violations, demonstrates both the capacity and a credible record in facilitating the development of human rights norms in domestic legal systems by enabling broader community or "public" interests to be recognised and enforced through the judicial process.

In order to assess PIL's capacity to foster human rights compliance, this article compares and contrasts its emergence and development in two jurisdictions, namely India and Australia. The two countries were chosen for the contrasts they provide - India, for its remarkable and extensive development of PIL, unparalleled in any Commonwealth jurisdiction to date, and Australia, for its adoption of a comparatively restrained and traditional trajectory in line with other members of the Commonwealth. Whilst PIL has evolved dissimilarly in the two countries, inevitably shaped by differences in culture, economic development, law and politics, ${ }^{5}$ both, however, provide illustrations of its potential in facilitating the development of human rights norms in domestic legal systems. In India, the development of PIL has been advanced by procedural changes which have included the expansion of legal standing to those acting bona fides without any

1 Mr Jose Ayala Lasso, Further Promotion And Encouragement Of Human Rights And Fundamental Freedoms, Including The Question Of The Programme Of Methods Of Work Of The Commission Follow-Up To The World Conference On Human Rights, UN Economic and Social Council, Commission on Human Rights $52^{\text {nd }}$ Session, 1995, E/CN.4/1996/50/Add.1 at para 9.

2 B Conforti, International Law and the Role of Domestic Legal Systems (The Hague: Sithoff, 1993) at 7 [Conforti].

${ }^{3}$ See ibid at 7.

${ }^{4}$ R Agarwal, "The Barefoot Lawyers: Prosecuting Child Labour in the Supreme Court of India" (2004) 21 Ariz J Int'l \& Comp L 663 at 675 [Agarwal].

5 S Susman, "Distant Voices in the Courts of India: Transformation of Standing in Public Interest Litigation” (1994) 13 Wis Int'l L J 57 at 63 [Susman]. 
requirement for a personal stake, the relaxation of litigation initiating procedures including the acceptance of letters as lodgement of a petition, the use of a fact finding approach more akin to inquisitorial than adversarial processes and the adoption of a flexible array of remedies. ${ }^{6}$ Such developments have enhanced access to the courts and enabled the interests of marginalised groups in the Indian community to be both represented and remedied as a result. Australia, in contrast has not replicated the developments in India favouring instead a traditional (although increasingly liberalised) approach to PIL where actions are generally reliant on plaintiffs with a personal stake in the matter and other procedural requirements have remained fixed within the traditional rules of ordinary litigation. ${ }^{7}$ Consequently, it cannot be claimed that there is a discrete and sustained movement of PIL in Australia as there is in India. In spite of this and the clear limitations on what it can achieve, PIL in Australia as in India has generated a body of jurisprudence and a level of governmental and institutional awareness that has contributed to the justiciability and implementation of human rights previously denied. ${ }^{8}$

Part II provides a short history of PIL in India and Australia within the context of the legal systems of the two countries; Part III describes and contrasts four procedural underpinnings of PIL in both jurisdictions, namely standing, initiating procedures, fact finding processes and remedies; Part IV first explains how PIL's public, rather than the private rights focus of ordinary civil litigation has fostered human rights compliance and then considers whether the relaxation of standing and other procedures in the Indian jurisdiction should be replicated in the Australian jurisdiction; and finally Part V concludes that whilst PIL has the capacity to address systemic violations of human rights through its focus on group or public rights, its potential is moderated by the stringency of procedural requirements as seen in the contrasting examples of India and Australia. However, although this article concludes that standing be relaxed and remedies expanded in the Australian jurisdiction to mirror India, there are strong reasons for keeping the remaining underpinnings or checks and balances in place.

\footnotetext{
${ }^{6}$ See ibid at 77.

7 See Australian Law Reform Commission (ALRC), Beyond the Doorkeeper: Standing to Sue for Public Remedies, ALRC Report No 78) (Canberra: ALRC 1996) at para [3.4] [Beyond the Doorkeeper].

${ }^{8}$ See A Durbach, "Conscientious Participation: Working the Law Back to its Bones" in R Hunter \& M Keyes, eds, Changing Law: Rights, Regulation and Reconciliation (Sydney: Ashgate, 2005) 155 [Durbach].
} 
Forster and Jivan: Public Interest Litigation in India \& Australia

\section{Public Interest Litigation: Setting the Scene}

PIL can be defined as litigation in which the public or the community at large has some pecuniary or legal right or interest. ${ }^{9}$ Whereas private rights litigation, which has historically dominated the legal landscape, is solely concerned with the declaration of an individual's rights and obligations, the grievance in a public interest action concerns the conduct and content of government action or policy in relation to constitutional, statutory or general law rights of a particular segment of society. ${ }^{10}$ PIL had its origins in the 1960 s in the socio-political context of the civil rights movement of the United States and was specifically utilised by civil organisations to assist the disadvantaged. ${ }^{11}$ Its emergence can, in part, be linked to fundamental changes in global legislative and constitutional provisions in the modern era which saw a shift from the prioritisation of individual interests to the protection of the interests of groups of individuals. Historically, the major function of courts in civil proceedings was the protection of private individuals and their interests by declaring and enforcing their private rights. However, the emergence of laws governing industrial relations, social welfare, and racial and gender quality, to name a few, invoked new notions of the community or groupings such as workers, the unemployed, women and racial minorities as the subjects of litigation. In both Australia and India, inspired by the emergence of the movement in the United States, lawyers pursued "public interest" cases at the instigation of activists, in an attempt to remedy the failure of government, administrative bodies and institutions to adequately represent and address marginalised interests. ${ }^{12}$ The developments, therefore, were driven primarily in both jurisdictions by those seeking to protect the rights of socially and economically disadvantaged groups. ${ }^{13}$ Initially, PIL in both countries closely followed the developments in the United States. However, by the end of the 1970s the two countries despite their common English jurisdictional heritage had begun to take very different paths.

In India, the political context of the 1970s had a marked impact on the legal system. A political crisis during the leadership of Indira Gandhi had culminated in the declaration of the Emergency of 1975. Gandhi issued a

\footnotetext{
${ }^{9}$ See Agarawal, supra note 4 at 675.

${ }^{10}$ See M Rao, Public Interest Litigation (Lucknow: Eastern Book Company, 2002) at 85.

${ }^{11}$ For example, Brown v Board of Education of Topeka (1954) 347 US 483, which is credited with birthing the PIL movement in USA. The landmark case successfully challenged and overturned precedents which had hitherto supported the segregationist policies in education. See also S Jain, Public Interest Litigation (New Delhi: Deep and Deep, 2002) at 28 [Jain] for a discussion of PIL in USA.

12 See M Gomez, "In the Public Interest" in Essays on Public Interest Litigation (Colombo: University of Colombo, 1993) 51 at 60 [Gomez].

${ }^{13}$ See Agarwal, supra note 4 at 689.
} 
Presidential Order suspending the right of any person to move any court (and any pending proceedings) for the enforcement of rights conferred by Articles 14, 21 and 22 of the Constitution. The Proclamation of Emergency received judicial and legal support in the case of ADM Jabalpur v Shiv Kan Shukla ${ }^{14}$ in which the Supreme Court denied the ability of the plaintiff to move the court for a habeas corpus challenging the legality of a detention order. The court went on to suspend the rights contained in Articles 14, 21 and 22 of the Indian Constitution for the entire period the Proclamation of Emergency was in force. The Emergency lasted until the general elections in 1977 when Indira Gandhi was removed from office and a period of significant change ensued. The new ruling party (the Janata Party) was feeling its way and opposition parties were finding new roles. ${ }^{15}$ Many rural Indians were resisting feudal arrangements and the responsibilities and authority of the state were in question. ${ }^{16}$ In response, the Supreme Court moved to redefine the lines between governmental authority and citizens' rights, injecting into the Indian court system a culture of judicial activism. ${ }^{17}$ Indeed, the Indian judiciary, considered to be the most activist in the world, is credited by many to have been pivotal to the development of PIL. ${ }^{18}$ The activism of the court, and the concomitant development of PIL, is in turn attributable in no small part to the unique machinations contained in the Indian Constitution developed in the post World War II era of human rights. ${ }^{19}$

The Constitution vests in the Indian courts both the responsibility of protecting human rights and wide ranging powers to facilitate and implement such rights. Articles 13-30 contain many of the (civil and political) fundamental rights and freedoms typically found in international covenants such as the right to equality before the law, the right to be free from discrimination, freedom of speech and freedom of assembly. ${ }^{20}$ The judiciary has interpreted these rights expansively, thereby increasing the kinds of violations that public interest petitions can seek to remedy. For example, Article 21, which protects the right to life, has been interpreted broadly to include, amongst other things, the recognition

\footnotetext{
14 (1976) AIR 1207 (SC).

${ }^{15}$ See Susman, supra note 5 at 65.

${ }^{16}$ See Susman, supra note 5 at 66.

17 Judicial activism is generally understood as describing situations when judges make law rather than merely interpreting the law. See S Sathe, "Judicial Activism: The Indian Experience" (2001) 6 Wash UJL \& Pol'y 29 for a detailed discussion of judicial activism in the Indian context.

${ }^{18}$ See S Sathe, Judicial Activism in India (New Delhi: Oxford, 2002) at 102 [Sathe].

${ }^{19}$ See Agarwal, supra note 4 at 689.

${ }^{20}$ V Sripati, "Human Rights in India-Fifty Years After Independence” (1997) 26 Denv J Int'l L \& Pol'y 93 at 97.
} 
of environmental rights, ${ }^{21}$ "the right to sweet water and the right to free air". ${ }^{22}$ In one case, the article was used by the Court to authorise its intervention in controlling examinations and their results on the basis that falling educational standards are important to mankind. ${ }^{23}$ Such rights and freedoms contained in Articles 13 to 30 can be actioned through the provisions contained in Articles 32 and 226. Article 32 guarantees the right to move the Supreme Court to provide a remedy for the breach of any of the fundamental rights and freedoms protected under the Constitution, whilst Article 226 of the Constitution provides that any person who has suffered harm categorised as a legal wrong can approach the relevant High Court in any state. Both the Supreme Court and the High Court can issue:

"to any person or authority, including in appropriate cases, any Government within those territories directions, orders or writs, including writs in the nature of habeas corpus, mandamus, prohibition, quo warranto and certiorari, for the enforcement of any of the rights conferred by Part III (fundamental rights and freedoms) and for any other purpose."

Additionally, the Constitution equips the Supreme Court with an expansive suite of remedies. Article 142 empowers the Court to issue decrees and orders for the purpose of "doing complete justice in any cause or matter pending before it". Such orders and decrees are enforceable throughout India through provisions including Article 141 which deems that "the law declared by the Supreme Court shall be binding on all Courts within the territory of India" and Article 144 which enjoins all authorities, civil and judicial, to act in aid of the Supreme Court.

Coupled with the above provisions and empowering the court to oversee the legislature and the executive are the "Directive Principles of State" (largely premised on the social, economic and cultural rights) contained in Part IV of the Constitution (Articles 36-51). The Directives are not "enforceable by any court" but are "fundamental in the governance of the country" 24 and it is the duty of the State to apply the principles in making laws. The Directives have amongst their objectives the reduction of inequalities in status and opportunity (Article 38) and the distribution of society's resources to serve the common good (Article 39). The substance of these articles, according to Bhagwati $\mathrm{J}$, is at the heart of PIL and has

${ }^{21}$ S Pani, Comparative Analysis of Environmental Activism through Constitutional Rights: Two Case Studies: India and Hong Kong (India: National Academy of Legal Studies and Research (NALSAR) (2002).

${ }^{22}$ Attakoya Thangal $v$ Union of India 1990 (1) KLT 580.

${ }^{23}$ See S Sarkar, Public Interest Litigations and Public Nuisances (New Delhi: Orient, 2003) at 465.

${ }^{24}$ Constitution of India 1949, Article 37. 
enabled the judiciary to further expand its capacity in PIL matters. ${ }^{25}$ The Directives do appear in particular to have had a significant role in the development of environmental PIL matters. ${ }^{26}$

Buttressed by such generous constitutional provisions, the Indian courts in the 1980s began to relax the rules and procedures governing PIL (discussed in full below). The hitherto rigid rules drawn initially from the British common law system were relaxed so as to provide ordinary people with opportunities to engage the legal system in the enforcement of their rights. ${ }^{27}$ India's social and economic situation, reflected in large scale poverty and general ignorance about the law and human rights, rendered more acute many of the socio-economic problems that typically form the basis of many public interest claims. ${ }^{28}$ The judicial reaction to cases brought in the public interest was in effect, therefore, a response to debilitating poverty and underdevelopment resulting from state repression, governmental maladministration, exploitation of disadvantaged groups and the denial of their rights and entitlements. ${ }^{29}$ The Supreme Court regarded itself as having an obligation "to secure justice for the poor and weaker sections of the community" and to "promote or vindicate the public interest, which demands that violations of constitutional or legal rights of large numbers of the poor, the ignorant or those in a socially or economically disadvantaged position should not go unnoticed or unredressed". 30 As Bhagwati J surmised, providing access to justice for large masses of people who are denied their basic human rights can only be achieved if the court adopts innovative new methods and devises new strategies. ${ }^{31}$ In India, therefore (at the instigation of civil society) the activism in the courts in response to widespread poverty and the expansive provisions of the constitution, have become the driving forces in the development of PIL. ${ }^{32}$ In particular, the focus in India on state repression and government lawlessness, rather than as in the United States (and Australia) on public participation in governmental decision-making led Baxi to coin the term "social action litigation", to describe and distinguish the Indian phenomena and equivalent of PIL. ${ }^{33}$

\footnotetext{
${ }^{25}$ P Bhagwati, “Judicial Activism and Public Interest Litigation” (1985) 23 Colum J Transnat'l L 561 at 570 .

${ }^{26}$ See for example Sachidanand Pandey $v$ State of West Bengal (1987) AIR SC 1109.

${ }^{27}$ See Susman, supra note 5 at 67 for an overview of this process.

${ }^{28}$ Jain, supra note 11 at 3.

${ }^{29}$ See Jain, supra note 11 at 3.

${ }^{30}$ People's Union for Democratic Rights $v$ Union of India (1982) 2 SCC 235.

${ }^{31}$ SP Gupta v Union of India (1982) AIR SC 149.

${ }^{32}$ See Agarwal, supra note 4 at 689.

${ }^{33}$ U Baxi, "Taking Human Suffering Seriously: Social Action Litigation: Before the Supreme Court of India" in N Tiruchelvan \& R Coomaraswamy, ed, The Role of the Judiciary in Plural Societies (New York: St Martin's Press, 1987).
} 
In contrast, in the Australian jurisdiction the development of PIL was measured and did not involve the dramatic procedural changes that had occurred in India. This can be attributed in part to (discussed in full below) first, an absence of PIL-oriented provisions in the Australian constitution; second, the largely conservative approach to judicial activism adopted by the Australian High Court; and third, its differing political context leading to the development of alternate mechanisms for the implementation of human rights in the Australian jurisdiction. In contrast to the Indian Constitution, the Australian Constitution does not contain guaranteed fundamental human rights nor does it incorporate any of the enabling provisions that the Indian judiciary has harnessed to relax procedural rules and facilitate the development of PIL. Additionally, the socio-political context in which the Australian Constitution evolved was very different to that which gave rise to the Indian Constitution. Australia, unlike India, had (allegedly) been settled, ${ }^{34}$ not invaded, and a penal colony past coupled with a dispossessed minority Indigenous population saw the emergence of a very different constitution to that of modern India. ${ }^{35}$ The impetus to include fundamental rights and freedoms was not as urgent as in India and the focus of the Australian Constitution therefore lay in establishing a Federation and the delineation of the powers between the states and the new Federal government, leading some to describe it as a "treaty between the states" rather than a "people's constitution". ${ }^{36}$ Williams notes that "customs duties and tariffs, and the capacity of the upper house of the federal Parliament to veto money bills, were of far greater concern than the protection of human rights." 37 The few express provisions found in the Constitution relating to human rights focus primarily on protecting civil and political rights. ${ }^{38}$ Further, such rights have been significantly limited by both statutory restrictions and very narrow judicial interpretation. ${ }^{39}$ The historical use of implied rights in the constitution has been similarly restrained. In 1994, the

34 See L Behrendt, Indigenous Rights and the Australian Constitution: A Litmus Test for Democracy (Conference Papers Constitutions and Human Rights in a Global Age: An Asia Pacific Perspective, 2001), online: <http://rspas.anu.edu.au/pah/human_rights/papers/2001/Behrendt.pdf.>

35 See G Williams, Human Rights Under the Australian Constitution (Melbourne: Oxford University Press, 2002) at 26 [Williams].

${ }^{36}$ See ibid at 27. See also J A La Nauze, The Making of the Australian Constitution (Melbourne: Melbourne University Press, 1972) at 190 and G Williams, The Australian Constitution and Human Rights: A Centenary View (Conference Papers Constitutions and Human Rights in a Global Age: An Asia Pacific Perspective, 2001), online: $<$ http://rspas.anu.edu.au/pah/human_rights/papers/2001/Williams.rtf. $>$ [Williams].

${ }^{37}$ See Williams, supra note 36.

${ }^{38}$ See for example s 41 the right to vote; s 80 the right to trial by a jury; s 116, the right to freedom of religion; s 117 freedom from discrimination on the basis of State residence; and s 51(xxxi) the right to just compensation.

${ }^{39}$ See Williams, supra note 36 at 3 who notes that s 80 provides for jury trials only in indictable matters and s 41 applies to state Houses of Parliaments only. 
Australian High Court read into the Constitution an implied right on freedom of political communication which paved the way for the discovery of further implied rights. That right, however, has since been curtailed ${ }^{40}$ and no further implied rights have been read into the Constitution. Unsurprisingly, therefore, many view the two countries' differing constitutional positions as a significant factor in the explanation and evolution of the different models of PIL in the two jurisdictions. ${ }^{41}$

The Australian political context in the 1970s, in contrast to the crisis of the Emergency in India, was characterised by the establishment of a welfare state. The Whitlam Labour Government, from its election in 1972 onwards embarked on an extensive welfare programme, involving dramatic increases in social spending and a more "universalist" approach to welfare. As a result this era was associated with considerable legislative reform and the introduction of government funded "welfare-oriented" forms of legal delivery such as the establishment of community legal centres and legal aid. The impact of this context on the development of PIL was twofold. First, the provision of welfare services and the absence of widespread poverty, in contrast to India, meant the issues requiring redress in Australia through PIL were not economic or social in nature (such as the provision of basic services, right to access to drinking water, the provision of adequate shelter or the provision of basic health facilities). Instead the issues, which required litigation, aimed to secure rights in the areas of civic participation in governmental decision-making and defending interests not affiliated to individuals such as indigenous rights and environmentalism. ${ }^{42}$ Second, the series of legislative reforms passed by the Commonwealth and state parliaments from the mid 1970s onwards saw the establishment of a range of statutory bodies and tribunals to oversee governmental action and to an extent aid the implementation of human rights. In 1976, the Ombudsman Act 1976 (Cth) established the Office of the Ombudsman to function as watchdog over the executive. The Ombudsman operates independently, with wide powers to obtain information, to investigate complaints and make recommendations to the relevant administrator. The establishment of tribunals at the national level including the Social Security Appeals Tribunal (1975) and the Administrative Appeals Tribunal ("AAT") (1976) ${ }^{43}$ also furthered the government's agenda in this area and such initiatives cumulatively operated to reduce the urgency of the PIL movement in Australia. In fact, the creation of a general tribunal for the review of

\footnotetext{
40 Theophanous $v$ Herald and Weekly Times (1994) CLR 104. See also Australian Capital Television Pty Ltd v Commonwealth (No 2) (1992) 177 CLR 106.

${ }^{41}$ See Gomez, supra note 12 at 59.

42 See Agarwal, supra note 4 at 689.

43 The reforms of the 1970s were based on the recommendations of the report of the Kerr Committee which was charged with reassessing the "fragmented and confused state of review of administrative decisions in Australia". Kerr Committee, Overview of the Commonwealth System of Administrative Review (Canberra: ALRC, 1971).
} 
administrative decisions (the AAT), not only provided a timely check on governmental decision-making but also according to Downes was at the time and remains today unique in the common law world. ${ }^{44}$ Indeed, tribunals with powers to settle disputes and enforce decisions proved to be simpler, cheaper, and faster than going to court and. as a result, such developments were replicated in the states to the extent that tribunals came to outnumber courts by two to one. ${ }^{45}$ Unlike its federal counterparts the jurisdiction of state tribunals was not limited to administrative disputes but extended to include equal opportunity, consumer, trading and tenancy matters. Further, the enactment of the Freedom of Information Act 1982 (Cth) ("FOI Act"), described as an integral part of Australia's democratic framework added another dimension to the availability of public rights. $^{46}$ The FOI Act aimed to make government more open and accountable by providing the public with a statutory right of access to information in the possession of government. Such moves towards affording more rights continued in Australia into the 1980s with the enactment of the Human Rights and Equal Opportunity Act 1986 (Cth) which established a statutory corporation (the Commission) to administer three anti-discrimination Acts. The Commission was empowered to inquire into whether enactments, acts or practices were inconsistent with human rights, to provide advice to government, to provide education in relation to human rights and to promote human rights and equal opportunity in employment.

The rapid establishment of such monitoring bodies and tribunals since the 1970 s, which have not been replicated to the same extent in India, ${ }^{47}$ arguably

44 Justice Downes, "Overview of Tribunals Scene in Australia" Speech delivered at the International Tribunal Workshop, Canberra (5 April 2006), online: $<$ http://www.aat.gov.au/SpeechesPapersAndResearch/speeches/downes/OverviewTribunalsScene April2006.htm>.

${ }^{45}$ R Creyke, "Better Decisions and Federal Tribunals in Australia" (2004) 84 Reform Issue 10 at 14, online: < http://www.austlii.edu.au/au/other/alrc/publications/reform/reform84/3.html $>$.

${ }^{46}$ Criticisms levelled against the FOI, however, include that the system is cost prohibitive, it is confusing and difficult for applicants to use, its exemptions are unclear, it is open to misuse by agencies and the Act undermines efforts towards increased openness. ALRC, "A Review of the Freedom of Information Act 1982 (Cth)" (Canberra: ALRC, 1995) at para [2.12].

${ }^{47}$ Note, however, recent moves in India to establish similar mechanisms such as the creation of a Human Rights Commission in 2000. Part XIVA of the Indian Constitution, in particular Articles $323 \mathrm{~A}$ and B authorise the establishment of tribunals for "administrative and other matters." Although this provision has not been utilised extensively, tribunals have been set up such as the Income Tax Appellate Tribunal, the Company Law Board, the Sales Tax Appellate Tribunal, the Consumer Forums, the Central and State Administrative Tribunals and the Debt Recovery Tribunal, online: $<$ http://www.llrx.com/features/indian.htm $>$. See also the recent enactment of the Freedom of Information Act 2005, online: $<$ http://www.privacyinternational.org/countries/india/india-v-adr-foia-502.pdf. $>$. Note also that despite several attempts an Ombudsman (Lokpal) has not been established at the central government level. However, 17 states have adopted the institution of Lokayukta (the state 
slowed the need for, and the consequent development of a strong PIL movement in Australia since their functions realised some of the very aims PIL in India sought to achieve. The next section will consider four significant differences in PIL that have emerged between the two jurisdictions, namely the judicial and legislative approach to locus standi, the initiating or lodgement procedure of PIL, the investigative or fact-finding processes and finally the form and extent of remedies.

\section{Public Interest Litigation in India And Australia: A Comparison of Key Procedural Differences}

\section{A. Locus Standi}

Locus standi or the law of standing is the set of rules that determine whether a person who initiates legal proceedings is a proper person to do so. Although both public and private law have standing rules, in private law the entitlement to apply for a remedy is generally considered satisfied if an applicant can meet the material elements of the action, such as establishing the presence of an injury in the tort of negligence. In public law, however (where public interest litigation is situated) standing is a discrete preliminary issue which determines an applicant's right to seek a remedy prior to the merits of the proceeding being heard. ${ }^{4}$

Standing in most public law actions in Australia requires some level of personal stake or interest in the matter litigated. Despite calls for a unified test ${ }^{49}$ the courts currently use a medley of "personal interest" tests to resolve the issue of standing in Australia. The particular level of personal interest depends in the general law on the remedy sought by the plaintiff and in statutory law the particular test designated by the statute governing the situation. Recent developments, however, in both statute and the general law, have cumulatively marked a liberalisation of the standing rules leading some to note a gradual trend towards "open standing". 50 Historically, in the general law, only the AttorneyGeneral had standing to vindicate, by way of injunctive or declaratory relief, the

equivalent of the Ombudsman). K Rai, Public Interest Lawyering, Legal Aid and Para- Legal Services, $2^{\mathrm{d}}$ ed, (Allahabad: Central Law Publications, 2004) at 327. The government has also established a range of industry ombudsmen over the last decade in sectors such as banking, insurance and telecommunications.

${ }^{48}$ See M Allars "Standing: the Role and Evolution of the Test" (1991) Fed L Rev 83 at 91; M Aronson \& B Dyer, Judicial Review of Administrative Action (Sydney: LBC, 2004) at 644 [Aronson].

${ }^{49}$ See Beyond the Doorkeeper, supra note 7 at paras [4.5]-[4.8].

${ }^{50}$ Aronson, supra note 48 at 647. 
"public interest" in public law matters. ${ }^{51}$ There are two ways that the power of the Attorney-General can be invoked in this capacity. First, the Attorney-General as "the guardian of the public interest" can lodge a claim, ex-officio, on behalf of the public interest if the remedy sought is an injunction or a declaration. ${ }^{52}$ Alternatively, if approached by a plaintiff the Attorney-General can issue a consent called a fiat which allows the plaintiff to initiate proceedings as a relator (ex relatione) ${ }^{53}$ However, these are rarely issued and if the Attorney-General fails to issue a fiat the refusal cannot be challenged in the courts. Further, if the fiat is granted, the Attorney-General retains control over the conduct of any proceedings. ${ }^{54}$

The exclusive power of the Attorney-General to take proceedings in the "public interest", however, has diminished over the 20th century as a result of both the growth of statute law (which incorporates its own standing tests) and an increasing number of exceptions in the general law initiated by the case of Boyce $v$ Paddington Borough Council (Boyce). ${ }^{55}$ In Boyce the court held that if an applicant could show either that his private right had been interfered with at the same time as his public right or that the plaintiff had suffered "special damage peculiar to himself" in the "public" right to be vindicated then standing could be granted. Although the Boyce rule was interpreted narrowly by the courts throughout the 20th century, it was restated in two important cases in the early 1980s leading to the broadening and liberalisation of the standing rules in Australia. The first, Australian Conservation Foundation Inc v Commonwealth ${ }^{56}$ (the $A C F$ case) concerned a proposal to establish a tourist resort in central Queensland. Before approval for finance could be granted an environmental impact report was required under the Environment Protection (Impact of Proposals) Act 1974 (Cth). Believing that approval was to be given without the proper fulfilment of the requirements of the Act, the Australian Conservation Foundation sought an injunction and a declaration to halt the project pending the outcome of a properly conducted impact assessment. Although the Foundation was not granted standing, the case is significant because the court identified a new test for standing, replacing the requirement for "special damage peculiar to

\footnotetext{
${ }^{51}$ C Mantziaris, "The Federal Division of Public Interest Suits by an Attorney-General" (2004) 25 Adel LR 212 at 213 [Mantziaris].

${ }^{52}$ See ibid at 217.

${ }^{53}$ A fiat was granted to the Australian Catholic Bishops Conference in Re MvBain; Ex parte Australian Catholic Bishops Conference (2002) 209 CLR 372. However, the High Court was critical of the grant on the basis that the Attorney-General was attempting to circumvent the rules of standing and that the proceedings did not belong to the Bishops Conference but rather remained with the Attorney-General.

${ }^{54}$ See Mantziaris, supra note 51 at 218.

${ }^{55}$ [1903] 1 Ch 109.

${ }^{56}$ (1980) 146 CLR 493.
} 
himself" with a requirement that the applicant demonstrate a "special interest" in the subject matter of the litigation. Justice Gibbs described the previous special damage test as "apt to be misleading". He also stated that the new "special interest" test should not be limited to pecuniary loss although he precluded individuals or organisations which have a "mere intellectual or emotional" concern such as the litigants in the case at hand, which as an interested conservation group had an "ideological" interest only. ${ }^{57}$ Shortly afterwards, in Onus $v$ Alcoa of Australia ${ }^{58}$ the High Court confirmed that non-material interests can also constitute a special interest. The case concerned the construction of an aluminium smelter which the Aboriginal plaintiffs argued would interfere with their people's relics on the land and would contravene the Archaeological and Aboriginal Relics Preservation Act 1972 (Vic). The court held that the Act created public rather than private rights and that the plaintiffs did have a "spiritual and cultural" special interest greater than other members of the public including other Aboriginal persons who were not of their people.

Following the above two cases, further liberalisation of the rules of standing has occurred in a range of ways. First, statutory frameworks, increasingly the source of public interest litigation, have gradually incorporated more flexible standing tests, which in turn have been liberally interpreted by the courts. Such tests include "a person aggrieved", "a person dissatisfied", "and a person affected", "a person interested" or "a person with sufficient interest" test. ${ }^{59}$ In the Trade Practices Act 1974 (Cth), the broad standing provision extends to "any person" and the court has held the words are to be applied literally without qualifications, although, it should be noted that this is an exceptional provision specific to the nature of the Act. ${ }^{60}$ In some instances the general law "special interest" test has "heavily influenced" the interpretation of statutory tests such as the "person aggrieved" test ${ }^{61}$ and in other cases the statutory test has been given wide scope. For example, in Booth v Bosworth ${ }^{62}$ (the Flying Fox case) standing was granted on the basis of the statutory test "a person interested" to a member of

\footnotetext{
${ }^{57}$ See ibid at para 20 as per Gibbs J.

58 (1981) 149 CLR 27.

59 For example the Administrative Decisions Judicial Review Act 1977 (Cth) (ADJR) ss 3, 5 which state that a person must be aggrieved to the extent that their interests are adversely affected by the decision or conduct being challenged.

${ }^{60}$ See Truth About Motorways Pty Ltd v Macquarie Infrastructure Investment Management Ltd [2000] 200 CLR 591.

${ }^{61}$ See for example North Coast Environment Council Inc v Minister for Resources (1994) 55 FCR 492 where the court's interpretation of the person aggrieved test in the ADJR Act was based on the general law "special interest" test resulting in a finding that the Council had an interest not merely "intellectual or emotional" in the granting of a licence to export woodchips. See R Creyke \& J McMillan, Control of Government Action. Text, Cases and Commentary (Sydney: Butterworths, 2005) at 857.

${ }^{62}$ (2001) 114 FCR 39.
} 
Forster and Jivan: Public Interest Litigation in India \& Australia

a conservation group who sought a prohibitory injunction under the Environmental Protection and Biodiversity Act 1999 (Cth) to prevent a farmer from deliberately electrocuting thousands of flying foxes to protect his lychee crop. ${ }^{63}$ Second, the special interest test has been applied beyond the context of the $A C F$ case (which concerned injunctions and declarations) to writs of prohibition or certiorari where the court now uses a "special interest in the subject matter" test. ${ }^{64}$ In cases concerning writs of mandamus the applicant must have a "real" interest, a "sufficient interest" or a "legal, pecuniary or special interest". 65 Additionally, the meaning of "special interest" itself has broadened to the extent that rather than providing a positive account of persons satisfying the special interest criterion the courts have established a catalogue of persons and interests to whom they would not give standing. Persons in this category include those with a "mere intellectual or emotional" interest, on the basis that a person would not possess a special interest if he or she would be unlikely to gain an advantage "other than the satisfaction of righting a wrong, upholding a principle or winning a contest". ${ }^{66}$ The list of barred persons and interests also includes those with environmental or planning concerns without participation rights, those with economic interests or ownership or residential interests, and commercial rivals. ${ }^{67}$ Finally, in relation to public interest groups, the Australian courts appear to have been more liberal with standing if certain factors are realised. Positive factors include the following: first, whether the group is representative of a significant public concern; ${ }^{68}$ second, whether the litigants have an established interest in the area; third, whether the litigants have a relationship with government that has been recognised in legislation or through submitted reports (apparently thereby placing legitimate representative status on the group); fourth, prior participation in the relevant process and the absence of other possible applicants; and finally the ability to mount an effective challenge. ${ }^{69}$

${ }^{63}$ See C McGrath, "The Flying Fox Case” (2001) 18 (6) Envt'l Planning L J 540.

${ }^{64}$ Ex parte Helens Valley/Boya Assn Inc); State Planning Commission and Beggs (1989) 2 WAR 422.

${ }^{65}$ Although this test has been more restrictively applied than other prerogative writs there are examples of more liberal interpretations. See for example Mirror Newspapers Ltd v Waller [1985] 1 NSWLR 1 where a newspaper was given standing to seek a mandamus in relation to a decision of a coroner to prohibit the publication of evidence in a murder investigation.

${ }^{66}$ See $A C F$ case, supra note 56 as per Gibbs $\mathrm{J}$ at [5.30].

${ }^{67}$ See Aronson, supra note 48 at 653-674.

${ }^{68}$ However, note that in the $A C F$ case, supra note 56 , where according to Davies J the litigants were a "major national conservation organisation" standing was not granted.

${ }^{69}$ See for example North Coast Environment Council Inc v Minister for Resources, supra note 61, where standing was granted in an action requesting reasons for the granting of a licence to export woodchips with significant reliance on the fact that the Council was the "peak environmental group" in the region, had been recognised by the Commonwealth since 1977 as a significant and 
The general approach to standing in India is modelled, like Australia, on the British legal tradition of standing requiring a personal stake of some kind in the matter. ${ }^{70}$ Where the enforcement of a private right is sought by an individual, standing requires the litigant to have suffered a legal injury or wrong as in Australia. ${ }^{71}$ However, if an action relates to a public injury or a public wrong and if it is characterised as "public interest" litigation, the rules of standing have progressively been liberalised so as to remove almost all obstacles for potential litigants. Such changes to the rules of standing (for actions characterised as public interest litigation) were foreshadowed in the Indian Supreme Court in 1978 when a plaintiff was permitted to lodge a writ petition objecting to the torture of a fellow prisoner, a matter in which he had no personal stake. ${ }^{72}$ However, it was not until four years later, in Gupta $v$ Union of India ${ }^{73}$ that the move towards liberalised standing in public interest matters was identified and defined. In doing so Bhagwati J stated "any member of the public having sufficient interest can maintain an action for judicial redress for public injury". He also noted that as long as the person is acting bona fide with a view to vindicating the cause of justice" then the person can seek an appropriate "direction, order or writ" to seek judicial redress for a legal wrong committed against a person who is unable to approach the court because of "poverty, helplessness, or disability or a socially or economically disadvantaged position". ${ }^{74}$ Bhagwati J grounded the authority for his ruling in the Indian Constitution asserting that Articles 32 and 226 (outlined previously) confer the right to "anyone" (although not expressly stated in the provisions) to move the court and that the "appropriate" proceedings' referred to in Article 32 of the Constitution includes the enforcement of fundamental rights and freedoms. The test for standing in public interest matters since Gupta, therefore, now extends to any person with "sufficient interest" and it is the interpretation of this test which has led to a significant expansion of standing in the Indian context.

Ostensibly, the Indian test is not dissimilar to the "special interest" test used in Australia. However, the point of contrast between the two jurisdictions is that the Indian test requires the "genuine" concern of the litigant "deeper than that

responsible environmental organisation and given regular grants, has been on advisory committees, and have coordinated projects and conferences on environmental issues.

${ }^{70}$ See Charanjit Lal $v$ Union of India AIR (1951) SC 41 where it was held that no one except those whose rights were directly affected by a law could initiate proceedings.

${ }^{71}$ P Bakshi, Public Interest Litigation (New Delhi: Ashoka Law House, 2004) at 49.

${ }^{72}$ Sunil Batra $v$ Delhi Administration et al (1978) AIR SC 1675. The petitioner, a convict under a death sentence, through a letter to one of the Judges of the Supreme Court alleged that torture was practised upon another prisoner by a jail warder, to extract money from the victim through his visiting relations. The letter was converted into a habeas corpus proceeding.

73 (1982) AIR SC 149.

74 (1982) AIR SC 149. 
of a busybody" in the matter, rather than, as in the Australian context, a personal interest marked by loss, injury or wrong that is greater than that merely of the general public. In fact, the Indian test requires that litigants ("ideally public spirited persons" or a body of registered individuals such as a registered society) do not have a personal interest to ensure they are not acting for any personal gain. Consequently, a disinterested plaintiff is to be preferred to an interested plaintiff as he will not be bought off easily or face the pressure of a "test case" that an interested individual might. ${ }^{75}$ Specifically excluded from PIL actions, therefore, are those acting for personal gain, those acting to protect private property ${ }^{76}$ or out of political motivation ${ }^{77}$ or a personal grudge. ${ }^{78}$ The range and disparate nature of the persons who have qualified for standing thus far illustrates the point. In $D C$ Wadhera $v$ State of Bihar ${ }^{79}$ the court held that a professor of political science who had undertaken substantial research and was "deeply interested" in ensuring the proper implementation of the constitutional provisions, was given standing to challenge the practice of the state of Bihar in repromulgating a number of ordinances without obtaining the approval of the legislature. Likewise in Common Cause $v$ Union of India, ${ }^{80}$ a registered society with no personal connection with the matter was given standing to file a petition seeking a ban on the collection, storage and supply of blood in blood banks operating throughout India due to deficiencies in their methods. In Meera Massy ${ }^{81}$ a professor was given standing to challenge the appointment of lecturers without the prescribed qualifications on the basis that he had a "genuine" interest in the standards of education. The point is further illustrated by the considerable number of cases brought by high profile Supreme Court advocates and legal academics to whom standing has been granted on the basis of their "proven" interest in benefiting the underprivileged. For example, Dr B Wadhera (mentioned above), an advocate of the Supreme Court of India and a prolific PIL litigator has lodged numerous actions seeking a range of outcomes including, inter alia, the compelling of the Municipal Corporation of Delhi to remove and dispose of garbage in the city; ${ }^{82}$ second, an order seeking that vendors cease using recycled plastics; ${ }^{83}$ third, the reactivation of government

\footnotetext{
${ }^{75}$ SP Gupta v President of India (1982) AIR SC 149 [Gupta].

${ }^{76}$ Raunaq International Ltd v IVR Construction Ltd (1999) 1 SCC 492.

${ }^{77}$ See Gupta, supra note 75.

78 The judges have always excluded petitions which are motivated by personal grudges like Chhetriya Pradhushan Mukti Sangharsh Samiti v State of UP AIR 1990 SC 2060 and Subhash Kumar v State of Bihar AIR 1991 SC 420.

79 (1987) AIR SC 579, SC.

${ }^{80}$ (1996) AIR SC 929 [Common Cause].

${ }^{81}$ Meera Massy v S R Malhotra (1998) AIR SC 1153.

${ }^{82}$ Dr B L Wadhera v Union of India (1996) 2 SCC 594.

${ }^{83} \mathrm{Dr} B \mathrm{~L}$ Wadhera $v$ Union of India (1998) HC CWP 4447(unreported).
} 
drug price control mechanisms to stop increasing prices for medicines; ${ }^{84}$ and fourth (although not lastly) preventing Delhi University from re-employing retired teachers and paying them both a pension and a salary. ${ }^{85}$ Such liberalisation in PIL matters has not been confined in India to the issue of locus standi. A similar approach has also been adopted for initiating procedures, although as discussed in the next section, such robust changes have not been replicated in Australia.

\section{B. The Initiating Procedure}

Initiating procedures, or the means of lodging a public interest claim, can and has had a significant impact on the development and effectiveness of PIL. In particular, the means by which actions may be initiated may directly impact on access to the judicial process by dictating the level of resources and the expertise required for pursuing such actions. In Australia, rules as to the form and substance of the lodgement procedure must be strictly adhered to in public interest matters, as in ordinary civil litigation. Proceedings must be formally commenced by one or more litigants. The statement of claim must be drafted in a particular form for lodgement and must be executed by qualified legal practitioners. It must be lodged at the appropriate location and the appropriate fee must be paid or waiver sought. To attract free legal representation such as legal aid the initiator must come within that organisation's definition of public interest or seek alternate sources of funding. ${ }^{86}$ The lodgement process in Australia, therefore, requires considerable time, expertise and financial resources.

In the Indian jurisdiction, in ordinary civil litigation the same formal requirements as in the Australian jurisdiction must be met. ${ }^{87}$ In contrast to Australia, however, procedural rules in relation to the lodgement of PIL have been significantly relaxed. Whilst PIL proceedings can be commenced in the same way as ordinary litigation, ie by formal petition, ${ }^{88}$ developments over the last 40 years have seen an extraordinary relaxation of the traditional formal rules of lodgement, to the extent that "letters, postcards, telegrams and even newspaper items" have been accepted as writ petitions. ${ }^{89}$ Such developments had their genesis in the case of Sunil Batra v Delhi Administration ${ }^{90}$ where a letter written and sent by a prison inmate to a judge of the Supreme Court (Justice Iyer) describing the torture of a fellow inmate was accepted as a valid lodgement. In a similarly extraordinary

\footnotetext{
${ }^{84}$ Dr B L Wadhera v Union of India (1999) HC CWP 3813 (unreported).

${ }^{85}$ Dr B L Wadhera v Union of India (1999) HC CMA No 9710 (unreported).

${ }^{86}$ See for example, Public Interest Advocacy Centre, homepage: $<$ http://www.piac.asn.au/about/>.

${ }^{87}$ See B Wadhera, Public Interest Litigation. A Handbook, (Delhi: Universal Law Publishing, $2003)$ at 61 [Wadhera].

${ }^{88}$ See Susman, supra note 5.

${ }^{89}$ See Wadhera, supra note 87 at 63.

${ }^{90}$ (1978) AIR 1765 (SC).
} 
case, a letter to the editor in a newspaper by a widow describing the non-payment by the Provident Fund of the family pension after her husband's death was read by a judge of the Gujarat High Court. On the basis of the newspaper clipping, the judge ordered a show cause letter to be issued to the Provident Fund Commissioner. The arrears were paid within weeks of the first hearing. ${ }^{91}$ After a series of similar cases, the Supreme Court justified the acceptance of letters and newspaper articles as valid means of initiating actions on the basis that "it would not be right or fair to expect a person acting pro bono publico to incur expenses out of his own pocket for going to a lawyer and preparing a regular writ petition for being filed." 92 The acceptance of petitions in such varied forms is legally justified, according to the Supreme Court, by Article 32 of the Constitution. ${ }^{93}$ Article 32(1) does not identify by what means a litigant should move the court but simply states that it must be "by appropriate proceedings". Although such letter petitions have become rare more recently due to sustained criticism, the court continues to forward letters received to lawyers as amicus curiae and invites them to prepare petitions based on the contents of the letters. ${ }^{94}$ Initiating procedures, therefore, are starkly different in the two jurisdictions as is the approach to and method of fact finding adopted in PIL matters, discussed in the next section.

\section{Adversarial or Inquisitorial Fact Finding: Contrasting India and Australia}

There are two main approaches to the resolution process of legal disputes. In the adversarial approach adopted by common law countries, which evolved from the medieval practice of the duel, the parties identify the issues in the dispute and the evidence, legal and factual, to be put before the court. Judges may seek to clarify the evidence before ruling on it but otherwise do not take an active part in the proceedings. The second, the inquisitorial system, adopted by many European countries is premised on and operates within a different rationale. Rather than deciding between the submissions of two opposing parties the courts adopt a more participatory role and conduct inquiries and investigations before reaching a decision. $^{95}$

In Australia, as in other common law countries, the primary approach to resolving disputes in the courts is adversarial and to date little exception has been

\footnotetext{
${ }^{91}$ See Susman, supra note 5 at 89.

${ }_{92}$ Bandhua Mukti Morcha v India (1984) AIR SC 802.

93 Ibid at 815; M Rao, Public Interest Litigation. Legal Aid and Lok Adalats (Lucknow: Eastern Book Company, 2004) at 28 [Rao].

${ }^{94}$ See Sathe, supra note 18 at 206.

${ }^{95}$ P Vines, Law and Justice in Australia: Foundations of the Legal System (Melbourne: Oxford University Press, 2005) at 241.
} 
made for public interest matters. A public interest litigant will face the legal representatives and arguments of the "defendant" (who in public interest litigation is the state or its representative) in court. Arguably the only relaxation that has occurred in the Australian jurisdiction is the easing of the requirements for amicus curiae, or friend of the court, in public interest matters. An amicus curiae is not a party to the proceedings and is limited to the presentation of an argument often at the request of the court on a matter upon which it seeks or is prepared to receive information. Although the traditional view is that an amicus curiae appears solely to assist the court where a party or interest in the case is wholly unrepresented, in some PIL cases an amicus has been permitted on the basis that a concerned individual or interest group should be given the opportunity to assert their views on the matter before the court. ${ }^{96}$

Whilst the Indian jurisdiction inherited its adversarial system from England, in more recent times in PIL matters, it has adopted an approach more akin to the inquisitorial system adopted by civil law countries. Indeed, the Indian Supreme Court has publicly admonished the use of the adversarial approach in PIL claiming such matters require instead a "cooperative and collaborative" approach due to the one-sided nature of legal processes where groups are often underfinanced, poorly organised and unable either to approach the court or to provide it with the relevant material. ${ }^{97}$ By this the court was not intimating it would accept evidence without providing an opportunity to the defendant to challenge it, but instead that it expected the State (the defendant in PIL matters) to assist the court in finding the truth rather than taking an adversarial position. The litigation, therefore, should not be conceived as against the State but rather to curtail illegalities committed on its behalf. ${ }^{98}$ In practice, Indian judges often play an active role in PIL proceedings, they have requested Brandeis Briefs (briefs that present factual or non-legal data), ordered commissions of inquiry to collect and investigate facts, as well as consulted with economic, sociological and other experts. ${ }^{99}$ The challenge and opportunity to the government and its officers to make basic human rights meaningful, therefore, has necessitated, according to the Supreme Court of India, the adoption by the courts of a more inquisitorial approach to PIL. 100

\footnotetext{
${ }^{96}$ See Re McBain [2002] HCA 16; 209 CLR 37 where the court allowed an amicus curiae representing the Roman Catholic Church to appear and argue for the validity of the Infertility Treatment Act 1995 (Vic).

${ }^{97}$ PU DR v India (1982) AIR $1473 \mathrm{SC}$ as per Bhagwati J at 1477. See Rao, supra note 93 at 13.

${ }^{98}$ See Sathe, supra note 18 at 207.

${ }^{99}$ See Susman, supra note 5 at 88.

${ }^{100}$ Bandhua Mukti Morcha v India (1984) AIR (SC) 802 at 811.
} 
Forster and Jivan: Public Interest Litigation in India \& Australia

\section{The Remedy}

The scope of the remedies, both in terms of what is offered and to whom they can be awarded, is an important aspect of the potential impact of PIL strategies on human rights implementation. In Australia, the remedies available for PIL are the same as those obtainable for any public law action (ie at common law the prerogative writs, principally certiorari, prohibition, and mandamus, and the equitable remedies of declarations and injunctions). Under statutory law, the main remedies are those available at the federal level under the Administrative Decisions (Judicial Review) Act 1977 (Cth), or under similar judicial review legislation at the state level in Victoria, Queensland, Tasmania, and the Australian Capital Territory. PIL actions in Australia both in common law and statutory law are governed by the principle of res judicata, ie the remedy is afforded to the litigant only. However, in a public interest action the remedy may benefit others who are in a similar position as the state may be forced to perform a duty previously neglected or it may be prevented from undertaking actions that are causing loss or harm to others other than the litigant. Thus, although the immediate remedy is availed only to the individual litigant, the value of a public interest action may be seen in the resultant precedent set by the test case that will in some instances afford new legal rights to an entire class of persons. Further, the Australian courts have also recently indicated a more flexible remedial approach to PIL. In Humane Society International Inc v Kyodo Senpaku Kaisha Ltd ${ }^{101}$ where the litigants sought an injunction to prevent Japanese whaling, the High Court held that an injunction could be granted in a PIL matter even if it is unlikely to be enforced on the basis of its "educative" purpose and benefit.

In contrast to the Australian approach, the Indian courts have expressly extended remedial delivery in PIL matters in three identifiable ways. First, the Indian courts have adopted a flexible array of remedies in PIL matters. As discussed earlier Articles 32 and 226 confer on the Supreme and High Courts the power to issue "directions, orders and writs" and Article 142 gives the Supreme Court the power to issue decrees and orders for the purpose of "doing complete justice in any cause or matter pending before it". Armed with such powers the courts have issued remedies ranging from directions to blood banks on how blood should be collected, stored and given for transfusion including suggestions on how blood transfusions could be made free from hazards ${ }^{102}$ to directions on preparing a scheme for the housing of pavement dwellers. ${ }^{103}$ In one case the Court rewrote a statute (thereby imposing statutory obligations on the State of Punjab) to include detailed directives on how, when and under what conditions previously

101 [2006] FCA 116 (Full Court).

${ }^{102}$ See Common Cause, supra note 80.

${ }^{103}$ Sodam Singh v New Delhi Municipal Corporation (1998) 2 SCC 727. 
exploited rickshaw operators could secure and repay loans. In that case, the Supreme Court asked the Commissioner to consult with drivers' unions and set up group property in the equipment as well as insurance schemes. It also went so far as to demand that the State of Punjab take steps towards replacing manual rickshaws with motorised scooters so as to remedy the health problems occasioned by traditional rickshaws. ${ }^{104}$ Further, the courts have issued orders to ensure the children of prostitutes are educated; ${ }^{105}$ orders that health checks and nutritious food be provided for children employed in the carpet industry; ${ }^{106}$ they have created regulations governing the caloric intake of mental patients, ${ }^{107}$ and issued orders for the rehabilitation of rape victims. ${ }^{108}$ The Indian courts have also adopted the unique principle ${ }^{109}$ of ordering the State to pay compensation for the infringement of fundamental rights in "appropriate cases" which the courts define as "gross and patent". Such compensation, however, is not intended to be commensurate with the loss of the victim but rather constitute a token amount. ${ }^{110}$

Second, in some instances directions and orders are quasi-legislative in that they are intended to and do have the status of law, for example, the landmark case of Vishaka \& others $v$ State of Rajasthan \& others ${ }^{111}$ where the sexual harassment code produced by the Supreme Court was given "legislative status" until legislation was enacted. Another example is provided by Laxmi Kant Pandey $v$ India $^{112}$ where the directions issued by the Court detailed the procedures and precautions to be followed in matters involving the adoption of Indian children by foreign adoptive parents. This direction was given the status of law until intercountry adoption laws were enacted.

Third (and ordinarily), a court order will extend to and bind only the parties to a matter and deliver a remedy only to the successful litigants. In the Indian context, however, since the litigant has no personal interest in the action which is brought on behalf of the public or a particular sector of the public he or she is, therefore, not an appropriate recipient of any remedy. This issue was considered and clarified in the case of Gopi Aqua Farms v India, ${ }^{113}$ where a previous decision of the Supreme Court which had banned certain types of shrimp cultures in fragile coastal areas on the basis of their negative effects on the

${ }^{104}$ Azad Rickshaw Pullers Union v State of Punjab (1981) AIR SC 14.

${ }^{105}$ Gaurav Jain v Union of India (1997) AIR SC 3021.

${ }^{106}$ Bandhua Mukti Morcha v Union of India (1997) 10 SC 549.

${ }^{107}$ Laxmi Kant Pandey v Union of India (1984) AIR SC 469.

${ }^{108}$ Delhi Domestic Working Women's Forum v Union of India (1995) 1 SCC 14.

${ }^{109}$ See L Tortell, Monetary Remedies for Breaches of Human Rights: A Comparative Study (Oxford: Hart Publishing, 2006) at 81- 82.

${ }^{110}$ See Sathe, supra note 18 at 235.

111 (1997) AIR SC 3011.

${ }_{112}^{12}$ Laxmi Kant Pandey v India (1987) AIR 232.

${ }^{113}$ Gopi Aqua Farms v India (1997) AIR SC 811. 
ecosystem and contribution to pollution, was challenged by shrimp breeders. The breeders argued that the court could not bind them but only parties to the litigation. The court ruled that the principle of res judicata did not (and could not logically) apply to PIL and that all shrimp breeders were bound by the judgement.

Finally, the Indian Supreme Court has (using Article 144 of the Constitution) supervised the implementation of its directions in many instances. Rather than trusting the executive branch, the court has set up monitoring committees for jails, women's protective homes, juvenile homes, mental asylums, and many others. Through judicial invigilation, the court has sought to improve the management and administration of numerous public institutions, evidencing the court's prioritisation of substance and effectiveness of the remedy over form. In doing so the court risks courting breaches of the separation of powers, a demarcation more strictly adhered to in the Australian jurisdiction, yet concomitantly it could not be accused of not seeking to achieve "complete justice" as it is charged to do under the Constitution. As a result the remedies awarded by the courts in the Indian context, are both more wide-ranging and wide-reaching than in the Australian context.

\section{Public InTERest Litigation AND Human Rights ImPlementation}

\section{A. Going Beyond the Individual: Finding Solutions for Systemic Human Rights Violations}

The ratification of an international convention imposes on a State Party the obligation to respect, protect and implement the rights within the convention. ${ }^{114}$ Fulfilment of such obligations requires and is generally achieved (and measured) through both de jure and de facto compliance. De jure compliance requires changes to national constitutions and domestic law to bring it in line with the obligations created by a convention. De facto or actual compliance requires that the obligations created under a convention are not just recorded in the laws of the country but implemented in practice with the intended results. In reality, however, many nations are slow to instigate legislative and constitutional changes post ratification. ${ }^{15}$ Further, even when human rights norms are incorporated into national constitutions and legislation their realisation in practice is often protracted. This is due in part to legal norms often being expressed in general or open-ended terms, leaving adherence to statutory requirements to the discretion of individuals, officials and bureaucrats who may fail to put in place policies to

\footnotetext{
${ }^{114}$ See the Maastricht Guidelines on Violations of Economic, Social and Cultural Rights, Maastricht, 1997 at para 6, online http://www.escr-net.org/resources_more/resources_more_show.htm?doc_id $=425803$

${ }^{115}$ See Conforti, supra note 3 at 7.
} 
ensure that such rights are realised in fact. ${ }^{116}$ Courts as adjudicators, offer victims of human rights violations a potential means of redress, although they can typically only review such failures once proceedings have been initiated.

In both India and Australia, litigation that seeks to enforce private rights has a limited impact on human rights compliance. This is due to several factors. Initially, litigation requires a harmed individual who can only litigate in relation to an individual harm they have suffered. ${ }^{117}$ The remedy, should the litigation succeed, is afforded only to the individual plaintiff. Limited benefits are, therefore, provided to others in a similar situation particularly if the matter is settled before the court proceedings. Additionally and crucially, compensation to a harmed individual or an injunction that prevents an isolated behaviour to protect an individual does little to change or address the structural underpinnings of many human rights violations which are often systemic and affect large classes of people. ${ }^{118}$ For example, providing a rape victim with compensation in a civil action, whilst recognising to some extent the victim's "human rights", does not address the institutional cause of rape or facilitate the recognition that men as a class need to develop "ethically appropriate" norms in relation to sexual conduct. ${ }^{119}$ Private rights litigation (or ordinary civil litigation), therefore, is an inefficient tool for human rights implementation particularly in cases where violations affect a group of persons, similarly situated, or in circumstances where the violation may be of a collective right. Collective rights are those that, whilst vested in each individual by virtue of her or his membership in a group, exist only because of the existence of the group and cannot be maintained by individuals alone. ${ }^{120}$ For example, the cultural rights of minority indigenous groups are linked to the preservation of their cultural identities as a group and, therefore, constitute collective rights. A further example is the right to be free from genocide which

\footnotetext{
${ }^{116}$ H Hershkoff \& D Hollander, "Rights into Action. Public Interest Litigation in the United States" in Many Roads to Justice (Ford Foundation, 2000) 95 at 102.

117 S Palmer, "Critical Perspectives on Women's Rights: The European Convention on Human Rights and Fundamental Freedoms" in A Bottomley, ed, Feminist Perspectives on the Foundational Subjects of Law (London: Cavendish, 1996) 223 at 225.

118 Systemic human rights violations in Australia range from historic and continuing breaches against its indigenous peoples to more recent violations against refugees. See Human Rights Consultation Committee, Rights, Responsibilities and Respect: The Report of the Human Rights Consultation Committee (Melbourne: HRCC 2005) at 6-9. K Armstrong, E Baldry \& E Chartand, "Human Rights Abuses and Discrimination against Women in the Criminal Justice System in New South Wales" (2007) 12(2) Austl J H R 203. In India, systemic human rights violations have been recorded against groups such as prisoners, street dwellers and women, to name a few. See C Forsyth, "Human Rights in India: Historical, Social and Political Perspectives" (2002) 61(2) Cambridge L J 480.

${ }^{119}$ See P Easteal, ed, Balancing the Scales. Rape, Law Reform and Australian Culture (Sydney: Federation Press, 1998) at 204.

${ }^{120}$ R Smith, International Human Rights (Oxford: Oxford University press, 2003) at 311.
} 
exists to protect an entire group and does not exist without the existence of the group it is meant to protect. Thus, whilst it is open for individuals to seek the assistance of the law to provide legal solutions for breaches of private rights it falls short, however, of being an efficient and viable course of action for vulnerable and disadvantaged groups.

Public interest litigation, in contrast to private rights litigation, specifically seeks the recognition and enforcement of a public right, the enforcement of which is in the public interest. It, therefore, offers through its focus on the community rather than the individual, considerable benefits over private rights litigation in the implementation of human rights norms since as Allars puts it "a normal feature of public interest litigation is that the benefits to be gained from the litigation will be of a collective nature". ${ }^{121}$ India and Australia, however, due to their distinctive procedural approaches, have differing capacities to remedy the structural underpinnings of many human rights violations. In Australia, the recognition of a legal right can result in that right becoming available to an entire class of persons as occurred in Re McBain. ${ }^{122}$ In that case, a doctor challenged legislation that denied access to in vitro fertilisation facilities to unmarried women. The Court found that the provision was in breach of the Sex Discrimination Act 1984, and by declaring the section ultra vires successfully bestowed the right to access in vitro fertilisation on all single and lesbian women in Victoria. The successful result also brought the state legislation of Victoria into compliance with Article 12 of the Convention on the Elimination of All Forms of Discrimination against Women (CEDAW), which requires States Parties to take all appropriate measures to eliminate discrimination against women in the field of health care in order to ensure equal access to health care services, including those related to family planning. However, despite such developments, the capacity of PIL in Australia to realise the rights of marginalised groups or collective rights is curtailed because (as with private rights litigation) an advocate who wishes to pursue PIL requires a litigant who can demonstrate a "special interest" in the public right which is either denied, unlawfully exercised or misapplied, with the remedy being limited to the litigants. However, the expansion of the meaning of special interest and developments in environmental law, ${ }^{123}$ although not yet replicated in human rights law, signify an increasing capacity of the Australian courts to respond to widespread and systemic harms.

\footnotetext{
${ }^{121}$ M Allars, Introduction to Australian Administration Law (Sydney: Butterworths, 1990) at 308 [Allars].

${ }^{122}$ See Re McBain supra note 96.

123 See S Blay \& K Bubna-Litic, "The Interplay of International Law and Domestic Law: The Case of Australia's Efforts to Protect Whales" (2006) 23 Envtl Planning L J 465; C Norton, "Special Interest No Longer? Public Interest Standing in Australia Takes a New Turn" (2001) 6(2) Asia Pac J Envtl L 183.
} 
In the Indian context, the purposes of PIL include "redressing public injury, enforcing public duty, protecting social, collective, 'diffused' rights and interests or vindicating public interest". ${ }^{124}$ In contrast to Australia, primarily because of the relaxation of the procedural requirements, PIL in India has greater potential for the direct recognition of the rights of large groups or classes of people and, in some contexts, collective rights. ${ }^{125}$ It has achieved this primarily in three ways, first though its ability (and practice) of awarding remedies to an entire class of persons, second through the status of its directions and orders as legislation, and finally through the relaxation of locus standi. ${ }^{126}$ Examples of these and the resultant enforcement of the rights of large groups of peoples are best illustrated by cases such as Vishaka in which the Indian Supreme Court developed a sexual harassment code and ordered its immediate implementation across the country. The remedy, given legislative status, was not limited to the individual victim of the litigation (a woman who was gang raped in her place of employment) but explicitly aimed at protecting all working women in India. A further example is provided by Centre for Enquiry into Health and Allied Themes $v$ Union of India ${ }^{127}$ where the court, after accepting the arguments of the petitioners that a ban on sex selection abortions was ineffective, issued a series of directions to both the central government and to the state governments to educate the public about the law and in particular why sex selective abortion should cease. The court ordered that a central supervisory committee be set up to meet every six months to monitor and review the implementation of the legislation and to ensure that states produced quarterly reports detailing the measures that were being taken to implement the Act. The remedy protected not only future generations of girls and the "public interest" but also the wider community by the implementation of principles of non-discrimination. A final example is provided by a PIL filed by the Forum for Fact Finding Documentation and Advocacy requesting the Supreme Court to order the central government and 11 state governments to take immediate steps to prevent child marriages from taking place. The petition called for strict enforcement of the existing Child Marriage Restraint Act 1929; the punishment of officials who fail to stop such marriages from taking place; compensation for girls whose marriages are solemnised and the instigation of criminal prosecutions by the State. It also requested the Court to order the national and state governments to launch official campaigns against child marriage and to make birth and marriage registration mandatory. The Supreme Court agreed and directed Parliament to draft a new law to replace the previous legislation. Consequently,

\footnotetext{
${ }^{124}$ See Gupta, supra note 75 at 192.

${ }^{125}$ See J Cotterell, "Third Generation Rights and Social Action Litigation" in S Adelman \& A Paliwala, eds, Law and Crisis in the Third World (London: H Zell, 1993) at 120.

${ }^{126}$ See Sathe, supra note 18 at 211.

127 (2001) 5 SCC 577.
} 
Forster and Jivan: Public Interest Litigation in India \& Australia

the Prohibition of Child Marriage Act 2006 was enacted bringing India in line with its obligations under both the Convention on the Rights of the Child 1989 and Article 16 of CEDAW, thereby providing protection for all children in India. ${ }^{128}$ Both India, and to a lesser extent Australia, have therefore successfully utilised PIL to recognise the rights of wider groups and classes of marginalised persons thereby demonstrating a capacity to achieve solutions that seek to address the systemic nature of human rights violations.

\section{B. Better Human Rights Implementation Through PIL: Is Procedural Flexibility the Answer?}

PIL's ability to achieve improved and more effective human rights implementation is facilitated in large part through the level of procedural access it permits. Restricting access to the courts through the use of standing rules and initiating procedures is likely to significantly limit the number and the type of public interest matters that reach the courts. ${ }^{129}$ In contrast, relaxed "open" standing provisions and lodgement requirements, as evidenced in the Indian jurisdiction clearly facilitate greater and easier access to the legal system. Open standing procedures enable voluntary human rights organisations, activists and other "public spirited" persons to litigate on behalf of those who have limited access to the judicial system of redress. ${ }^{130}$ Relaxed initiating procedures enable individuals and organisations to lodge claims without the costs of engaging lawyers and consequently fewer resources are required of the applicant. ${ }^{131}$ The next two sections consider whether the procedural innovations developed for PIL in the Indian jurisdiction might usefully be extended to the Australian jurisdiction to assist and further human rights implementation.

\section{Human Rights Implementation and Standing: to Relax or not to Relax?}

Relaxed standing in the Indian context, as discussed previously, has facilitated increased potential for human rights implementation in India. The question for Australia, therefore, lies in whether it also should move towards a system of open standing (as some commentators suggest) ${ }^{132}$ or whether valid considerations compel the maintenance of the requirement for "special interest" in public interest

\footnotetext{
${ }^{128}$ Forum for Fact Finding Documentation and Advocacy $v$ Union of India and others (2003).

${ }^{129}$ See J Krishnan, "Public Interest Litigation in a Comparative Context" (2003) 20 Buff Pub Int L $J 19$ at 19.

130 See Susman, supra note 5 at 87.

131 See Susman, supra note 5 at 87.

132 E Fisher \& J Kirk, "Still Standing: An Argument for Open Standing in Australia and England" (1997) 71 Austl L J 370; P Cane, "Open Standing and the Role of Courts in a Democratic Society" (1999) 20 Sing L Rev 23.
} 
matters. The arguments posited on this issue include the following: the first and by far the most traditional argument used against open standing is the prospect of applications for judicial review overwhelming the courts. Observers concerned about such floodgates claim that relaxed standing will place an unacceptable strain on resources leading to judicial overload and lengthy waiting periods. ${ }^{133}$ However, such claims appear ill-founded in the Australian context since the relaxation of a number of statutory standing tests has failed to materialise into a deluge of litigation. ${ }^{134}$ In the Indian context the increased caseload "overtaxing" the court system, both predicted and feared by the critics has been borne out by the huge number of petitions that have flooded India's higher courts with sources placing the number of letters being received by the Supreme Court at 150 per day. ${ }^{135}$ This has led to the establishment of a separate "cell" to receive and vet public interest claims. ${ }^{136}$ The increase in petitions, it can be argued, however, attests to the highest ideals of democracy, demonstrating the willingness and proactive engagement of citizens in accessing the judicial system to effect social change. The concomitant response of the judiciary in India to admit such claims also attests to the recognition of its role as not mere independent arbiters of a controversy but as active agents protecting the constitution and the rule of law. ${ }^{137}$ If the state engages in unlawful conduct then an inability to challenge such conduct would appear to be contrary to the rule of law. It has also been argued that the failure of a legal system to make provision for an increasing number of people with genuine grievances regarding their social and physical environment may encourage some to turn to socially undesirable ways of redressing grievances. In such cases, there are arguably other ways of addressing a large volume of petitions without depriving victims of human rights violations of a meritorious remedy. ${ }^{138}$

Second, detractors of open standing have argued that courts should be availed of the benefit of argument from those most closely affected by their decisions. Such litigants are most likely to present clear, well resourced and meritorious arguments. Indeed, the trial system depends upon well matched adversaries who each have a degree of motivation sufficient to ensure the issues will be defined and presented with vigour and skill to the court. ${ }^{139}$ The Indian judiciary has responded to this argument by declaring that PIL matters do not, and

\footnotetext{
${ }^{133}$ See Beyond the Doorkeeper, supra note 7 at [4.37].

${ }^{134}$ See Allars, supra note 121 at 307.

${ }^{135}$ See J Cassells, "Judicial Activism and Public Interest Litigation in India: Attempting the Impossible" (1989) 37 Am J Comp L 495 at 501.

${ }^{136}$ See ibid at 495.

${ }^{137}$ See Wadhera, supra note 87 at 23.

138 See Beyond the Doorkeeper, supra note 7 at [4.28].

139 See R Creyke \& J McMillan, Control of Government Action (Sydney: Butterworth, 2007 at 847.
} 
should not involve an adversarial approach since the "public interest" cannot involve two contesting parties but rather should be a process of ascertaining the duties and obligations of the state in relation to its citizens. In fact, as iterated earlier, a disinterested plaintiff is to be preferred to an interested plaintiff as he will not be bought off easily or face the pressure of a "test case" that an interested individual might. ${ }^{140}$

Third, open standing has been critiqued on the basis that it is persons who are most likely to have their interests affected who should have the opportunity to voice their concerns within the judicial system. Indeed, the Indian courts on more than a few occasions have been accused of paternalism in providing remedies for persons not participating in the process or in some instances without knowledge of the process. ${ }^{141}$ In addition, Cane argues that the represented must have some control or "democratic stake" over the conduct of the litigants. However, victims of human rights violations particularly in India but also in Australia may often not have the resources, time or expertise to mount a legal challenge to the legality of state conduct. ${ }^{142}$ For example, it is unrealistic to expect individual pavement dwellers in India to each pursue legal remedies when their most immediate needs such as food and shelter are not met. ${ }^{143}$ Further, in some public interest claims there will not be members of the public particularly affected more than others and with such diffuse interests it is more appropriate for the case to be represented by an interest group or public interest advocate. ${ }^{144}$

A fourth argument put forward against open standing concerns the usurping of PIL by conservative interests or by those who are not part of the "underprivileged classes" that PIL initially emerged to protect. Increased access to the courts for all must also inevitably mean (so the argument goes) greater access for conservative interests. Indeed, whilst McAuslan argues that to advance the public interest is "to adopt policies and practices which advance the good of all citizens directly or indirectly"145 Ogus claims what constitutes the public interest is more likely to be aligned with the values, ideological position and aspirations of those who are the victors in the political struggle. ${ }^{146}$ The possibility of creating opportunity for litigation that is contrary to human rights norms caused by a relaxation of standing rules is indeed evidenced in both the Indian and the Australian contexts. For example, cases have been brought in India by politicians

\footnotetext{
${ }^{140}$ SP Gupta v President of India (1982) AIR SC 149.

${ }^{141}$ See Susman, supra note 5 at 84.

142 See K Ashton, "Public Interest Litigation: Realising the Potential" (2001) Legal Action Group Policy 1 at 2.

${ }^{143}$ See Wadhera, supra note 87 at 33.

${ }^{144}$ See Allars, supra note 121 at 308.

${ }^{145}$ P McAuslan, "Public Law and Public Choice" (1988) 6(51) Mod L Review 681 at 687.

146 A Ogus, "Regulatory Law. Some Lessons From the Past" (1999) 12(1) L S 1.
} 
initiating PIL in furtherance of their political careers ${ }^{147}$ and litigation has been initiated to enforce the interests of the middle class, rather than the underprivileged. ${ }^{148}$ In Australia, business corporations and professional and trade associations have also brought PIL actions to avert government action and regulations that affect their business costs. ${ }^{149}$ In Ogle $v$ Strickland, ${ }^{150}$ two priests were given standing to apply for review of a decision of the Censorship Board to import a film the clergymen alleged was blasphemous, indecent and obscene. The Federal Court justified its decision to award the priests standing on the basis that they had a "special interest" that went beyond the ordinary members of the Christian community since it was "a necessary incident of their vocation". 151 Standing, however, was denied to the Right to Life Association which sought to challenge the failure of the state to take action under the Therapeutic Goods Act 1989 (Cth) to stop the trials of the pregnancy termination drug Mifepristone. The court's decision was made on the basis that the organisation did not have a special interest but merely an emotional or intellectual interest. ${ }^{152}$ Despite the opportunities for interest groups or individuals whose values do not accord with human rights norms to obtain standing in PIL matters, the failure to extend standing for this reason alone would appear both disproportionate and counterproductive.

A final argument proffered against broad standing rules is that any augmentation will result in greater legal and administrative uncertainty. Predictability would be significantly reduced and as Wheller J observed "there is a considerable public interest in the reliable and predictable public administration of the law". ${ }^{153}$ Further, as government agencies make numerous decisions it is undesirable that every decision should be at risk of challenge by persons with no personal interest in the matter and instead other forums should be used for debate and discussion on the functioning of government. However, others argue that the knowledge that laws and administrative decisions can be challenged in such fora will raise the standard of decision-making. In conclusion, therefore, the relaxation of standing in PIL matters in Australia fails to give rise to sustainable objections. Similar developments in standing, as evidenced in the Indian jurisdiction would not only enhance access to PIL and but also aid in the implementation of human rights in Australia.

${ }^{147}$ Dhronamraju Satyanarayan v T Tao (1988) AIR AP 144.

${ }^{148}$ Sachidanand Pandey $v$ State of West Bengal (1987)1 SCC 492.

${ }^{149}$ M Gomez, supra note 12.

${ }^{150}$ (1987) 71 ALR 41.

151 Ogle v Strickland (1987) 71 ALR 41.

${ }^{152}$ Right to Life Association Inc v Secretary, Department of Human Services and Health (1995) 56 FCR 50.

${ }^{153}$ Bridgetown/Greenbushes Friends of the Forest Inc $v$ Executive Director of Conservation and Land Management (1997) 18 WAR 126 at 130. 
Forster and Jivan: Public Interest Litigation in India \& Australia

\section{Human Rights Implementation: Initiating Procedures and Flexible Remedies}

As well as relaxing standing requirements, the Indian jurisdiction as discussed previously has also relaxed other procedural requirements including the initiating procedures, the adoption of an inquisitorial style approach to PIL matters and the use of a flexible array of remedies. Relaxing these variables has progressed PIL in India and has resulted in enhanced access to the courts and greater opportunities for human rights implementation. Should Australia, therefore, follow the Indian example or are there valid considerations that support the maintenance of current procedural requirements? The use of relaxed initiating procedures, such as allowing lodgement by letter has been criticised on the basis that it reduces opportunities to subject a claim to rigorous legal scrutiny by lawyers in line with the checks and balances put in place by the formal system. ${ }^{154}$ As Pathak J argues, the applicant's status may be unknown or uncertain, with the judge not knowing the motivation or the veracity of the person commencing the proceedings. Accordingly, no sense of responsibility can be attached to the communication and it falls upon the court to elicit the issues, thus straining the resources of the court. ${ }^{155}$ He states, "there is good reason for the insistence of a document being set out in a form or accompanied by evidence indicating that the allegations are made with a sense of responsibility by the person who has taken due care and caution to verify those allegations before making them". ${ }^{156}$ Finally, the absence of guidelines and excessive flexibility in the admission of cases arguably creates uncertainty and unpredictability in the system. ${ }^{157}$ In sum, it seems appropriate, therefore, that lodgement procedures remain within the traditional parameters in the Australian context.

Whilst the multiplicity of remedies utilised by the Indian judiciary (which can and have been tailored to address the complexities of different matters) demonstrates in the Indian context the potential of PIL as a means of facilitating creative and appropriate solutions for the human rights violations people face, the activism of the courts has nevertheless been criticised by some human rights activists. Critics argue that judges do not have the expertise and are ill-equipped to initiate such wide-reaching change. For example, some feminists have argued that the sexual harassment guidelines developed in Vishaka are inappropriate as they do not accord with the definition or the scope of sexual harassment as articulated by the CEDAW Committee in General Recommendation 19 to the Convention on the Elimination of All Forms of Discrimination against Women

\footnotetext{
${ }^{154}$ See Wadhera, supra note 87 at 35.

${ }^{155}$ See Wadhera, supra note 87 at 35.

${ }^{156}$ See Bandhua Mukti Morcha, supra note 100 at 840.

157 See Wadhera, supra note 87 at 35.
} 
1979. ${ }^{158}$ The judges developed the code, critics argue, without the debate and discussion which ought to surround such important law making. ${ }^{159}$ Others have claimed that the Indian courts have issued orders that are "detailed, specific and intrusive" and that, as in relation to other procedural innovations, judges are compromising their positions as neutral arbiters and instead encroaching on the lawmaking function of the legislature and breaching the separation of powers. Some argue that the Supreme Court in fashioning new remedies, particularly unenforceable orders, undermines its own authority. "A judicial system can suffer no greater lack of credibility than a perception that its order can be flouted with impunity."160

Additionally, the practice of the Indian courts in declaring legislation, "as a means of distributive justice" $" 161$ whilst arguably serving good purpose in the Indian context, appears to be both untenable and unlikely in the Australian context. The Indian Supreme Court has consistently challenged any separation of powers by engaging in lawmaking and usurping the functions of the legislature and the executive. It has distinguished and justified its forays into lawmaking by (allegedly) restricting its interference to situations where there has been an absence of law and policy resulting in breaches of fundamental rights. ${ }^{162}$ In Australia, in contrast, the converse appears to be the case. The divisions between the three arms of government are more pronounced and arguably much more strictly adhered to and enforced. Further, the ability and practice of the legislature to override decisions of the High Court through legislation (such as occurred in the native title case of Wik Peoples $v$ The State of Queensland) ${ }^{163}$ operates to restrict the potential of PIL in the Australian jurisdiction by placing checks on the decision-making ability of the courts.

Finally, the relaxation of procedure and the expansion of the cache of remedies available to litigants and the broader community has obvious judicial effects realised through the setting of legal precedent that either induces compliance with human rights norms or encourages States Parties to enact legislative change. However, there is also a range of beneficial extra-judicial

158 See General Recommendation 19 to the Convention on the Elimination of All Forms of Discrimination against Women 1979, CEDAW Committee, $11^{\text {th }}$ Session, 1992.

online http://www.un.org/womenwatch/daw/cedaw/recommendations/recomm.htm\#recom19

${ }^{159}$ L Field, “Along the Spectrum of Women's Rights Advocacy. A Cross-Cultural Comparison of Sexual Harassment in the United States and India" (2002) 25(5) Fordham Intl L J at 1205.

${ }^{160}$ See Susman, supra note 5 at 82.

${ }^{161}$ See Susman, supra note 5 at 82.

${ }^{162}$ For example in Vishaka supra note 110.

${ }^{163}$ Wik Peoples v Queensland (1996) 187 CLR 1. See G Marks, “Australia, Indigenous Rights and International Law" (2006) 6(22) Indigenous L Bull 20. 
effects that ensue as a result of PIL. ${ }^{164}$ These include PIL's ability to, first, mobilise human rights activists, civil society groups, lawyers and academics into a visible and persuasive movement; second, the creation of a forum and nexus where a number of powerful social actors, institutions and systems are forced to interact and consider human rights issues; and third, a capacity to engender awareness raising. ${ }^{165}$ Even where public interest litigation has been unsuccessful such as the earlier "Stolen Generations" cases in Australia (concerning discriminatory government policies and the systematic removal of Aboriginal children from their families), in which several community legal centres and Legal Aid Commission lawyers commenced legal proceedings against State and Commonwealth governments, ${ }^{166}$ the litigation heightened public and international awareness of the human rights violations leading to calls for a reparations tribunal to negotiate settlements (as established in Canada, South Africa and New Zealand). ${ }^{167}$ PIL also publicly exposes the gap between law "on the books" and reality thereby playing an important "protest" role exerting pressure on recalcitrant governments or private institutions. ${ }^{168}$ Thus, clearly in both jurisdictions despite the differences in procedural relaxation and the availability of flexible remedies, the extra-judicial effects of PIL have served to foster human rights implementation not only in direct ways (for example through the application of the Bangalore Principles) but also indirectly through awareness raising and heightened publicity of human rights violations.

\section{CONCLUSion}

This article has argued that PIL has an important role to play in human rights implementation in both India and Australia. In both countries PIL's emphasis on the community or the "public" interest, rather than the individual focus of private rights litigation, has fostered greater recognition of human rights norms. In India, this has been achieved primarily through the innovative use of procedural rules

\footnotetext{
164 PIL cases provide the judiciary with opportunities to apply interpretive aids such as the Bangalore Principles. The Bangalore Principles, adopted at a judicial colloquium in 1988 and widely accepted and cited in many jurisdictions, guide judges towards decision-making that is in line with human rights norms. In India, in public interest cases such as Chairman, Railway Board and others $v$ Mrs Chandrima Das and others (2000) AIR SC 988 the Principles were used by the courts to develop liberal interpretations of constitutional standards, thus enabling more effective protection of human rights.

${ }^{165}$ See H Hershkoff \& A McCutcheon, "Public Interest Litigation. An International Perspective" in Many Roads to Justice (USA: Ford Foundation, 2000) at 285.

${ }^{166}$ Williams $v$ The Minister Aboriginal Land Rights Act 1983 and The State of New South Wales [2000] NSW SC 255; Cubillo v Commonwealth of Australia [2001] FCA 1213.

${ }^{167}$ See Durbach, supra note 8 at 160.

168 See Jules Lobel, "Courts as Forums for Protest” (2004) 52 U C Davies L Rev 477.
} 
which has included the following: first, the relaxation of standing requirements, thereby increasing access and enhancing the mobilisation of community groups; second, relaxed initiating procedures which have facilitated increased access to the courts; third, the adoption of an inquisitorial approach thereby engaging the state as a collaborator rather than a combatant; and finally, the use of a flexible array of remedies enabling a single action to achieve redress for entire classes of marginalised groups. Although there are a number of important and well-founded concerns about the initiation of procedures through informal means (eg letters) and the use of remedial orders and directions as legislation, binding those not party to the litigation, there is nevertheless a very persuasive body of thought postulating that such measures have encouraged and continue to encourage better human rights implementation. Whilst Australia has not replicated the developments in India, favouring instead a traditional approach to PIL where actions are reliant on plaintiffs with a personal stake in the matter and where other procedural requirements have remain fixed within the traditional rules of ordinary litigation, the gradual relaxation of standing rules has still generated a body of jurisprudence and a greater level of governmental and institutional awareness that has contributed to the furtherance of human rights implementation in Australia. This article surmises, therefore, that PIL in India and Australia provides an interesting exposition of both the potential and the risks of using litigation to effect social change. Each has demonstrated that PIL is a strategy with the potential to facilitate the development of human rights norms in domestic legal systems through both creative (as seen in the Indian jurisdiction) and more traditional ways (as evidenced in Australia). This article concludes that, in the Australian jurisdiction, whilst the maintenance of current lodgement procedures seems appropriate, there seems little reason to maintain the rigidity that surrounds standing rules, fact finding processes and the range of remedies available in PIL. As Freeman puts it, "judicial decisions proclaim truths" "169 and the opportunities PIL provides through the democratisation of justice to influence and direct the production of those truths cannot be underestimated. Thus whilst private rights litigation may never penetrate and substantially redistribute wealth or power ${ }^{170}$ PIL, provided it is supported by the procedural, substantive and practical infrastructure necessary to effect change, demonstrates both the capacity and a credible record in facilitating the advancement of human rights implementation.

169 J Freeman Defining Family in Mossop v DSS: The Challenge of Anti Essentialism and Interactive Discrimination for Human Rights Litigation' (1994) 44 University of Toronto Law Journal 41 at 60.

${ }^{170}$ See Rao, supra note 93 at 33. 